\title{
Wernicke Encephalopathy as a Complication of Hyperemesis Gravidarum: Case Report
}

\section{Encefalopatia de Wernicke como complicação de hiperêmese gravídica: Relato de caso}

\author{
Ênio Luis Damaso ${ }^{10}$ Estella Thaisa Sontag dos Reis ${ }^{10}$ Felipe Alves de Jesus ${ }^{2}{ }^{\circledR}$

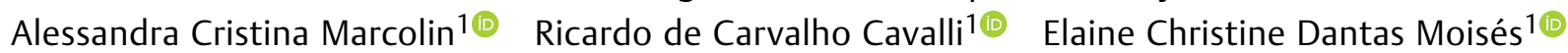 \\ 1 Department of Gynecology and Obstetrics, Universidade de São \\ Address for correspondence Ênio Luis Damaso, Master, Avenida \\ Paulo, Ribeirão Preto, SP, Brazil \\ Bandeirantes, 3900, Ribeirão Preto, SP, 14049-900, Brazil \\ 2 Department of Medical Imaging, Hematology, and Clinical \\ Oncology, Universidade de São Paulo, Ribeirão Preto, SP, Brazil \\ (e-mail: eniodamaso@yahoo.com.br).
}

Rev Bras Ginecol Obstet 2020;42(10):672-675.

\begin{abstract}
Keywords

- pregnancy

- Wernicke encephalopathy

- hyperemesis gravidarum

- thiamine

- case report

\section{Resumo}

Palavras-chave

- gravidez

- encefalopatia de Wernicke

- hiperêmese gravídica

- tiamina

- relato de caso

Wernicke encephalopathy (WE) is an acute neurological disorder resulting from vitamin B1 deficiency, which is common in chronic alcoholism. We report a rare case of WE due to hyperemesis gravidarum in a 25-year-old pregnant patient at 13 weeks and 5 days of gestation. Initially, the disease manifested as weakness, mental confusion, anterograde amnesia, and visual and auditory hallucinations. The diagnosis was established after the detection of suggestive findings of WE in the thalamus by magnetic resonance imaging (MRI) and a rapid improvement in the patient's clinical status subsequent to treatment with thiamine. Hyperemesis is a rare cause of WE, which makes the reported case important in the literature and reinforces the need for attention in clinical practice to rare but important complications of this common condition (hyperemesis gravidarum).

A encefalopatia de Wernicke (EW) é uma condição neurológica aguda resultada da deficiência de vitamina B1, muito comum em etilistas crônicos. Relatamos um caso de EW secundário a um quadro de hiperêmese gravídica em uma gestante de 25 anos de idade e 13 semanas e 5 dias de idade gestacional. Inicialmente essa desordem se manifestou como fraqueza, confusão mental, amnésia anterógrada, e alucinações auditivas e visuais. O diagnóstico foi estabelecido depois da detecção de achados sugestivos de EW na ressonância nuclear magnética e da melhora do quadro clínico com reposição de tiamina. A hiperêmese gravídica não é uma causa comum de EW, o que faz com que o presente relato de caso tenha importância na literatura e reforça a necessidade de atenção na prática clínica para complicações raras mas importantes desse quadro tão comum (hiperêmese gravídica).
\end{abstract}

received

May 12,2020

accepted

June 3,2020
DOI https://doi.org/

$10.1055 / \mathrm{s}-0040-1714721$. ISSN 0100-7203.
Copyright $\odot 2020$ by Thieme Revinter

Publicações Ltda, Rio de Janeiro, Brazil
License terms

(c) (i) 


\section{Introduction}

Nausea and vomiting are very common during pregnancy (NVP), affecting up to $80 \%$ of pregnancies. ${ }^{1-3}$ Hyperemesis gravidarum (HG), which can be described as severe NVP, affects up to $3 \%$ of all pregnancies and frequently leads to weight loss, dehydration, and electrolyte imbalance. ${ }^{2,4}$ Hyperemesis gravidarum is the most common indication for hospitalization in the first half of pregnancy. ${ }^{4}$ Maternal complications include dehydration, malnutrition and vitamin deficiencies, peripheral neuropathy, and more serious neurological complications, including central pontine myelinolysis and Wernicke encephalopathy (WE). ${ }^{2,4-8}$

The relation between WE and HG was described in 1939 by Sheehan. ${ }^{9}$ As this complication is rare, there is not much data about it in the literature. However, as it is a serious and rare complication, it deserves attention as a case report.

Here, we describe the case of a 25 -year-old pregnant female with WE due to HG.

\section{Case Report}

A 25-year-old pregnant patient at 13 weeks and 5 days of gestational age, in her third pregnancy, presented to our emergency department with symptoms of weakness, mental confusion, anterograde amnesia, and visual and auditory hallucinations.

One month before this first visit, the patient reports having presented hypoxia and vomiting. On examination, the patient was awake, disoriented, responding to commands, with isochoric and photoreactive pupils, absence of relative afferent pupillary defect, preserved visual acuity, exhaustible horizontal nystagmus, atypical gait, with slight dysbasia.

Laboratory tests showed the following changes: drop in hemoglobin levels ( $7.0 \mathrm{mg} / \mathrm{dl}$, reference: $11-16 \mathrm{mg} / \mathrm{dl}$ ), albu$\min (3.0 \mathrm{~g} / \mathrm{dl}$, reference: $3.5-4.8 \mathrm{mg} / \mathrm{dl})$ and potassium (3.3 $\mathrm{mmol} / \mathrm{l}$, reference: $3.5-5.5 \mathrm{mmol} / \mathrm{l})$, seric iron $(43.5$ $\mathrm{mcg} / \mathrm{dl}$, reference: $50-170 \mathrm{mcg} / \mathrm{dl}$ ), seric magnesium $(1.4 \mathrm{mg} / \mathrm{dl}$, reference; $1.7-2.5 \mathrm{mg} / \mathrm{dl})$ and increased liver enzymes glutamate pyruvate $(129 \mathrm{U} / \mathrm{L}$, reference $<41 \mathrm{U} / \mathrm{L})$ and transaminase glutamate oxaloacetate transaminase (61 $\mathrm{U} / \mathrm{L}$, reference $<31 \mathrm{U} / \mathrm{L}$ ). Transient hyperthyroidism was also observed, with TSH $(0.04 \mathrm{mU} / \mathrm{L}$, reference $0.3-4.0 \mathrm{mU} / \mathrm{L})$ below normal limits. Other complementary exams did not show alterations. Ultrasound showed single alive intrauterine fetus.

Magnetic resonance imaging (MRI), on T2/FLAIR sequence, showed symmetrically increased signal intensity in the dorsomedial thalami (-Figs. $\mathbf{1}$ and $\mathbf{2}$ ). This finding may suggest injury to the medial portion of the thalamus.

Due to the main diagnostic suspicion of WE, thiamine replacement was initiated with a $500 \mathrm{mg}$ intravenous loading

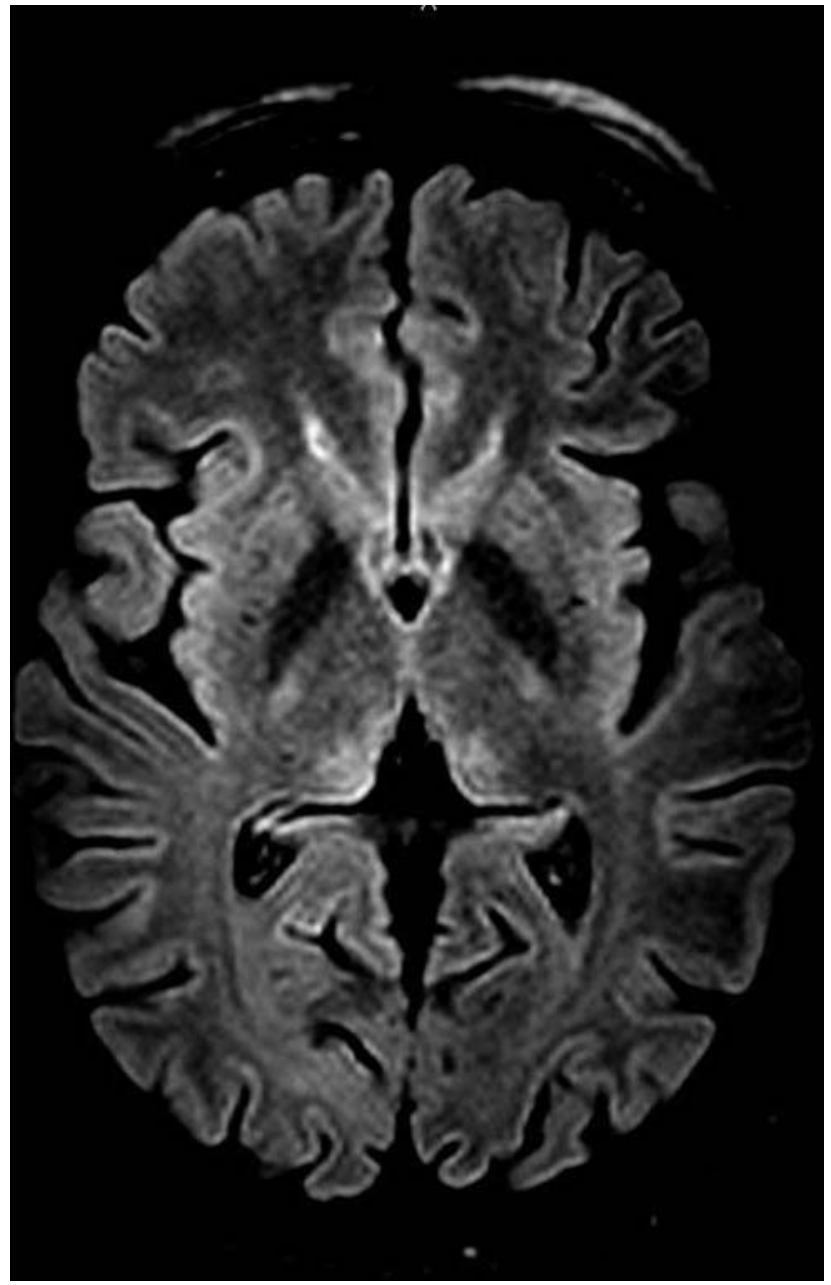

Fig. 1 Dorsomedial thalami.

dose every 8 hours for 3 days, and then maintained with $100 \mathrm{mg}$ orally for another 14 days. The patient also received potassium replacement orally, and 3 blood concentrates were transfused, after which she presented a slow improvement in her neurological condition, being discharged after 7 days of hospitalization for prenatal follow-up at our service.

During prenatal care, the patient evolved with improved thyroid function, and presented normal exams in 2 months. She was diagnosed with gestational diabetes mellitus but obtained good control with diet.

The fetus was diagnosed with ventriculomegaly (dilation of the cerebral ventricles) and intrauterine growth restriction during the morphological ultrasound in the second trimester.

The patient evolved to cesarean delivery at term due to altered fetal vitality. The newborn is being followed-up with genetics and neurology, with a probable diagnosis of DandyWalker malformation (DWM). 


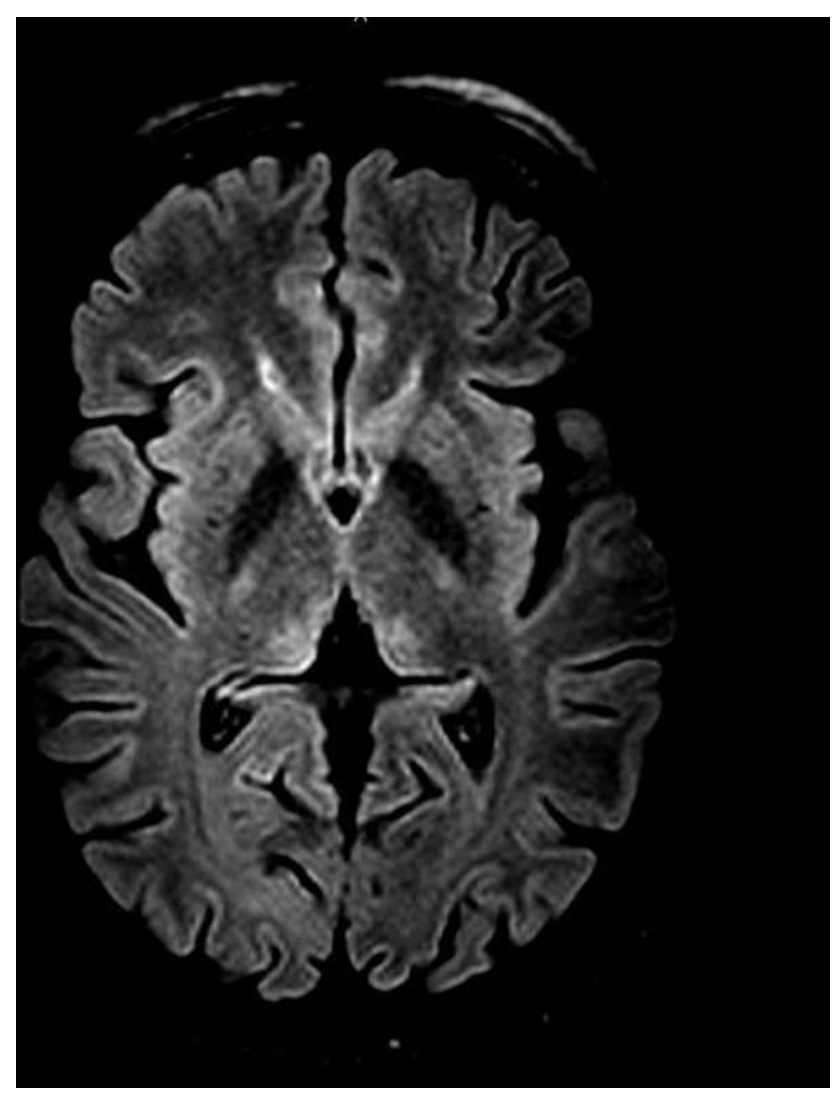

Fig. 2 Dorsomedial thalami (white arrows).

\section{Discussion}

The patient has presented neurological changes (nystagmus, disorientation) as well as a previous history of HG. The laboratory tests reinforced the finding of malnutrition (low levels of albumin and minerals), and the MRI showed alterations in the thalamus region. All these findings were suggestive of WE.

Wernicke encephalopathy is an acute neuropsychiatric syndrome characterized by the classic triad of ataxia, eye movement disorders, and mental status change. It is the result of a thiamine deficiency. ${ }^{4}$

The majority of patients that develop WE have a history of chronic alcoholism and accompanying malnutrition. ${ }^{2,8} \mathrm{Be}-$ fore the onset of WE, prodromal characteristics of severe thiamine deficiency are present, such as nausea and vomiting, and blurred or double vision. ${ }^{2,8,10}$ Inadequate treatment often results in additional characteristics of the classic triad consisting of oculomotor abnormalities, cerebellar dysfunction, and an altered mental state. The more symptoms of WE, the more likely chronic Korsakoff syndrome will develop: a cognitive disorder characterized by severe amnesia, executive problems, and confabulation, which leads to lifelong impairment. ${ }^{8,10}$ It is relatively unknown that HG can lead to WE.

Wernicke encephalopathy is better diagnosed by the Caine's operational criteria, since not all patients have the classic triad. Caine's operational criteria for WE are: Wernicke's classic triad; autopsy evidence of WE; or clinical response to thiamine. ${ }^{11}$ The defining signs and symptoms for WE were: dietary deficiencies, oculomotor abnormalities (reported as nystagmus or ophthalmoplegia), cerebellar dysfunction (reported as falling or imbalance), and an altered mental state (reported as delirium, confusion, and problems in alertness, or cognition). ${ }^{11}$

The body stores $\sim 25$ to $30 \mathrm{mg}$ of water-soluble vitamin thiamine (B1), which is good for $\sim 18$ days. The daily requirement is $0.4 \mathrm{mg} / 1,000 \mathrm{kcal}$ per day, which increases in pregnancy to $1.5 \mathrm{mg} /$ day. ${ }^{12}$ Deficiency of thiamine pyrophosphate, which is an important co-factor for enzymes in the pentose phosphate pathway, affects multiple tissues, particularly those with high thiamine turnover that include neural parenchyma resulting in cell necrosis or apoptosis. ${ }^{13}$

Wernicke encephalopathy in pregnancy generally occurs in women who are malnourished, due to the increased demands of pregnancy. Hyperemesis further depletes thiamine stores. ${ }^{14}$ However, WE is uncommon in pregnancy but HG is pretty common. Wernicke encephalopathy generally occur at 14 to 18 weeks gestation after 2 to 3 weeks of vomiting, which was the case with our patient who presented at 13 weeks and 5 days gestation with history of vomiting for 1 month. ${ }^{13}$

The diagnosis of WE is primarily clinical. In his operational criterion for the identification of WE, Caine et $\mathrm{al}^{11}$ proposed that WE is diagnosed if any two of the following four signs exist: ophthalmoplegia, ataxia, altered mental status, and malnourishment. Nystagmus is the most common ocular sign and confusion is the most common presenting symptom. ${ }^{11}$

The diagnosis may be reinforced by a brain MRI, which shows symmetric high T1, T2, and T2 flair signal intensities in the mammillary body, medial thalamus, periventricular, and periaqueductal regions. The sensitivity and specificity of brain MRIs are 53\% and 93\% for the diagnosis of WE, respectively. $^{15}$

The gold-standard treatment is to replace thiamine, which results in the resolution of symptoms in a few hours to a few days depending on the severity of the disease. If untreated, WE can progress to WernickeKorsakoff syndrome (WKS), resulting in more chronic symptoms such as anterograde amnesia, which takes more time to resolve after treatment. ${ }^{16}$ Therefore, diagnosis and treating as fast as possible will result in less severe disease.

Dandy-Walker malformation (DWM) or syndrome is a posterior fossa anomaly characterized by agenesis or hypoplasia of the vermis and cystic enlargement of the fourth ventricle causing upward displacement of tentorium and torcula. ${ }^{17}$ DWM may be isolated or associated with chromosomal abnormalities, Mendelian disorders, syndromic malformations, congenital infections, and various other comorbidities. ${ }^{18}$ There is no description in the literature of cases of DWM in pregnant women complicated with HG or WE. And we cannot infer that thiamine deficiency or nutritional changes lead to brain formation. 


\section{Conclusions}

Wernicke encephalopathy is an uncommon and life-threatening neurological disease complicating pregnancy in the setting of hyperemesis. Timely and serious management of vomiting in pregnancy and replacement of thiamine stores help treat acute neurological symptoms and can prevent both maternal and fetal morbidity.

\section{Conflict of Interests}

The authors have no conflict of interests to declare.

\section{References}

1 Niebyl JR. Clinical practice. Nausea and vomiting in pregnancy. N Engl J Med. 2010;363(16):1544-1550. Doi: 10.1056/NEJMcp1003896

2 Oudman E, Wijnia JW, Oey M, van Dam M, Painter RC, Postma A. Wernicke's encephalopathy in hyperemesis gravidarum: A systematic review. Eur J Obstet Gynecol Reprod Biol. 2019; 236:84-93. Doi: 10.1016/j.ejogrb.2019.03.006

3 Jarvis S, Nelson-Piercy C. Management of nausea and vomiting in pregnancy. BMJ. 2011;342:d3606. Doi: 10.1136/bmj.d3606

4 Gazmararian JA, Petersen R, Jamieson DJ, Schild L, Adams MM, Deshpande AD, Franks AL. Hospitalizations during pregnancy among managed care enrollees. Obstet Gynecol. 2002;100(01): 94-100. Doi: 10.1016/s0029-7844(02)02024-0

5 Birkeland E, Stokke G, Tangvik RJ, Torkildsen EA, Boateng J, Wollen AL, et al. Norwegian PUQE (Pregnancy-Unique Quantification of Emesis and nausea) identifies patients with hyperemesis gravidarum and poor nutritional intake: a prospective cohort validation study. PLoS One. 2015;10(04):e0119962. Doi: 10.1371/ journal.pone.0119962

6 van Stuijvenberg ME, Schabort I, Labadarios D, Nel JT. The nutritional status and treatment of patients with hyperemesis gravidarum. Am J Obstet Gynecol. 1995;172(05):1585-1591. Doi: 10.1016/0002-9378(95)90501-4

7 Fejzo MS, Macgibbon KW, Romero R, Goodwin TM, Mullin PM. Recurrence risk of hyperemesis gravidarum. J Midwifery
Womens Health. 2011;56(02):132-136. Doi: 10.1111/j.15422011.2010.00019.x

8 Sechi G, Serra A. Wernicke's encephalopathy: new clinical settings and recent advances in diagnosis and management. Lancet Neurol. 2007;6(05):442-455. Doi: 10.1016/S1474-4422(07)70104-7

9 Ashraf VV, Prijesh J, Praveenkumar R, Saifudheen K. Wernicke's encephalopathy due to hyperemesis gravidarum: Clinical and magnetic resonance imaging characteristics. J Postgrad Med. 2016;62(04):260-263. Doi: 10.4103/0022-3859.191005

10 Isenberg-Grzeda E, Kutner HE, Nicolson SE. Wernicke-Korsakoffsyndrome: under-recognized and under-treated. Psychosomatics. 2012;53(06):507-516. Doi: 10.1016/j.psym.2012.04.008

11 Caine D, Halliday GM, Kril JJ, Harper CG. Operational criteria for the classification of chronic alcoholics: identification of Wernicke's encephalopathy. J Neurol Neurosurg Psychiatry. 1997;62 (01):51-60. Doi: 10.1136/jnnp.62.1.51

12 Chataway J, Hardman E. Thiamine in Wernicke's syndrome-how much and how long? Postgrad Med J. 1995;71(834):249. Doi: 10.1136/pgmj.71.834.249

13 Kotha VK, De Souza A. Wernicke's encephalopathy following Hyperemesis gravidarum. A report of three cases. Neuroradiol J. 2013;26(01):35-40. Doi: 10.1177/197140091302600106

14 Gárdián G, Vörös E, Járdánházy T, Ungureán A, Vécsei L. Wernicke's encephalopathy induced by hyperemesis gravidarum. Acta Neurol Scand. 1999;99(03):196-198. Doi: 10.1111/j.16000404.1999.tb07344.x

15 Xie B, Si ZZ, Tang WT, Qi HZ, Li T. Wernicke encephalopathy in a patient after liver transplantation: A case report. World J Gastroenterol. 2017;23(47):8432-8436. Doi: 10.3748/wjg.v23.i47.8432

16 Sabatini JS, Schutz-Pereira GL, Feltrin F, Teive HAG, Camargo CHF. Wernicke's encephalopathy with chorea: Neuroimaging findings. Dement Neuropsychol. 2016;10(04):370-372. Doi: 10.1590/ s1980-5764-2016dn1004020

17 Treviño Alanís MG, González Cantú N, Montes Cruz JV, García Flores JB, Martínez Menchaca HR, Rivera Silva G. [Dandy Walker malformation]. Arch Argent Pediatr. 2014;112(01):103-104. Doi: 10.5546/aap.2014.103

18 Robinson AJ. Inferior vermian hypoplasia-preconception, misconception. Ultrasound Obstet Gynecol. 2014;43(02):123-136. Doi: 10.1002/uog.13296 